\title{
Mini-Cluster on Teaching about the $1 \%$, the Rich, the Upper Class, the Ruling Class
}

\author{
by Marcial González, Greg Meyerson, and Richard Ohmann
}

Note

Marcial González, Greg Meyerson, and Richard Ohmann worked together on these three articles. We spoke on a panel organized by the Radical Caucus of the Modern Language Association for MLA's 2014 convention. Our topic was "Teaching About the 1\%, the Rich, the Upper Class, the Ruling Class .... . As that list suggests, we meant to explore common ways of conceptualizing the wealthiest people in the U. S., and in capitalist society generally. We argued that the best way is to see them structurally, as integral to a class system. And we sketched out ways for teachers to do that.

Radical Teacher published a mini-cluster in issue \#85 (Fall, 2009) on teaching about the upper class. The editors invite further discussion of this subject.

$$
-M G, G M, R O
$$

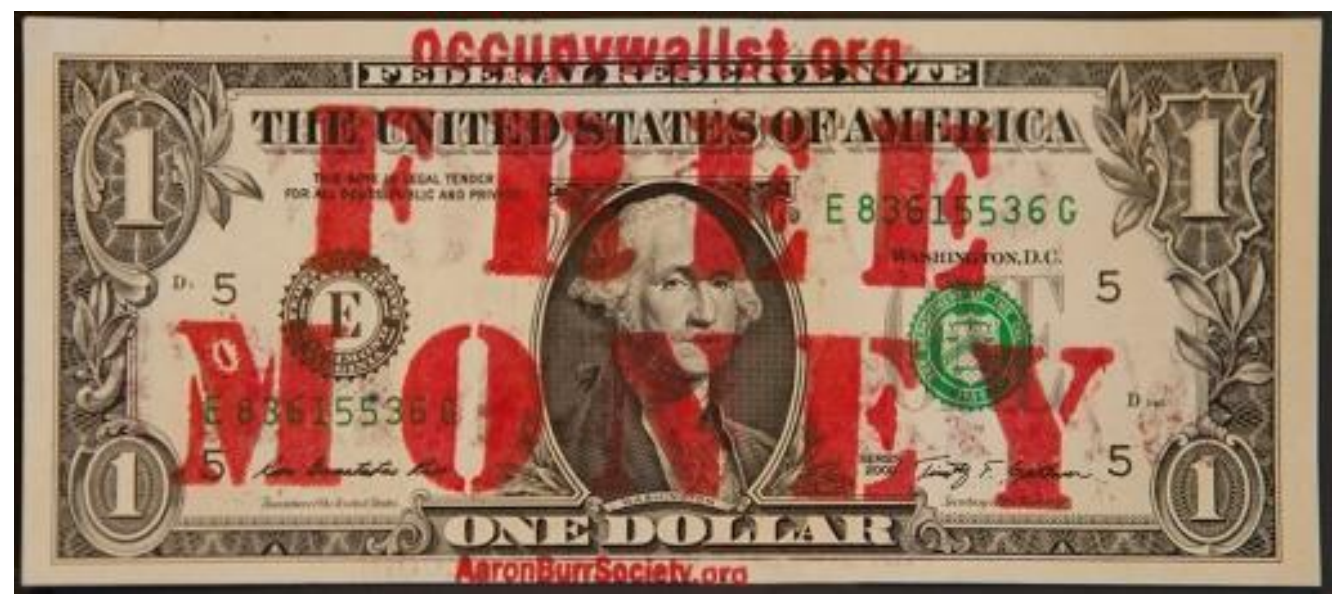

COURTESY OF AARON BURR SOCIETY JIM COSTANZA 


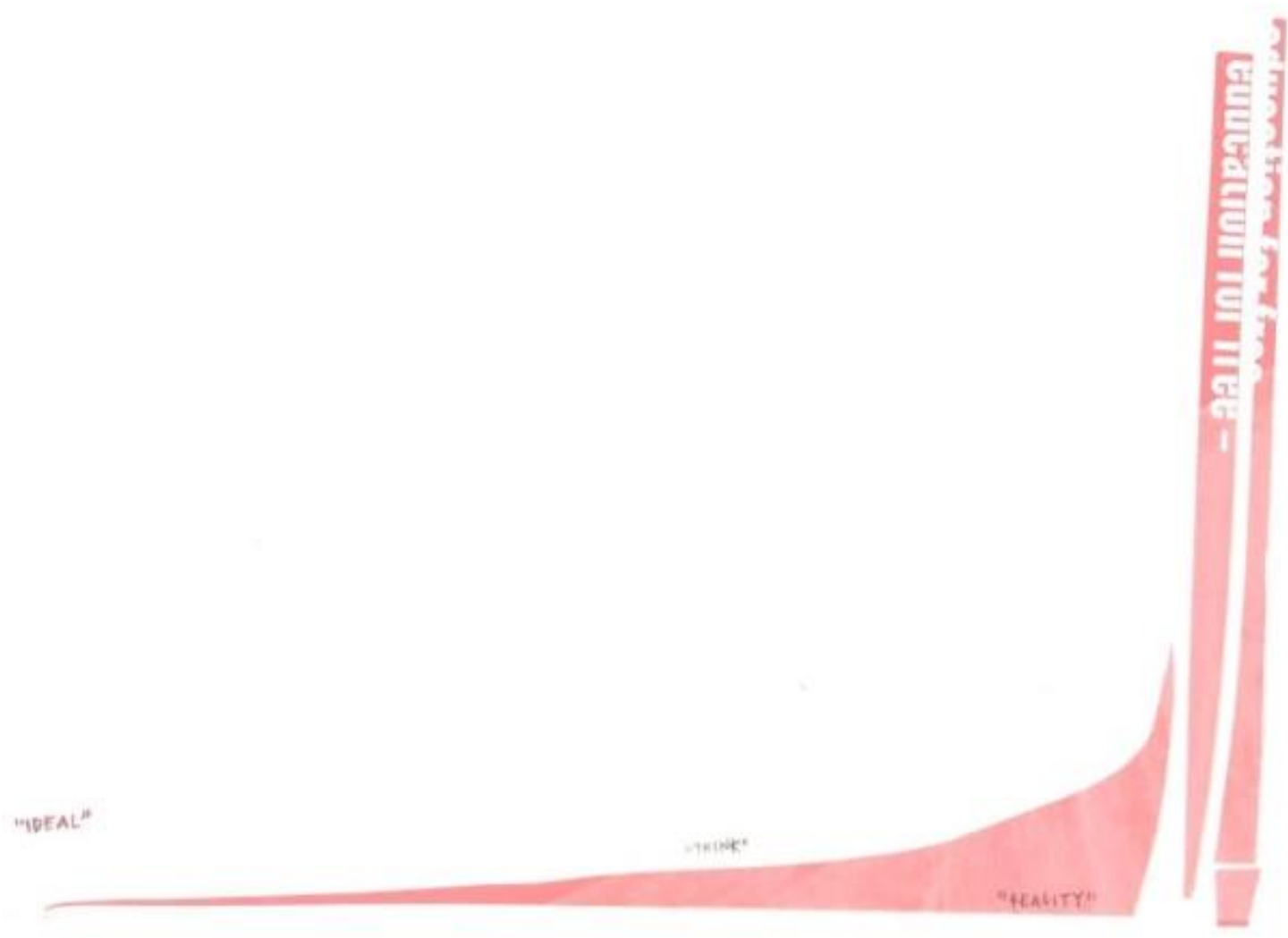

"INEQUITY GRAPH" COURTESY OF SHINA YOON

\section{$(\mathrm{cos})$ EY-NC-N0}

ULLS D-Sorle
This work is licensed under a Creative Commons Attribution-Noncommercial-No Derivative Works 3.0 United States License.

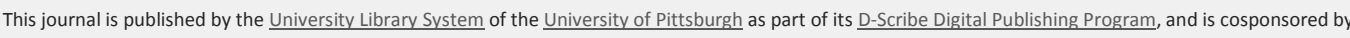
the University of Pittsburgh Press.

\section{RADICAL TEACHER}

http://radicalteacher.library. pitt.edu
No. 101 (Winter 2015)

DOI $10.5195 /$ rt.2015.196 